\title{
Critical Review on the Theoretical Framework and Critical Success Factors in Green Construction
}

\author{
Afzan Ahmad Zaini and Intan Rohani Endut
}

\begin{abstract}
Construction activities must conserved energy, land, water and material to successfully implementing green construction, while planning and managing the work regarding the minimisation of environmental impacts related to the construction process. Notwithstanding this, many arguments and discrepancies between the ideal form of green construction and existing construction due to the practical difficulties in realizing the concept of green construction. This paper critically reviews the existing green building assessment tools, theoretical framework and the critical success factors based on literature review search. Investigating the existing green building assessment tools, theoretical framework and critical success factors are fundamental in determining the successful implementation of green construction in the Malaysian construction environment.
\end{abstract}

Keywords Critical success factors - Green building assessment tools - Theoretical framework - Green construction - Malaysian construction environment

\section{Introduction}

Construction industry in Malaysia is considered the fastest developing country in Asia and has contributed 3-7 \% to the Gross Development Product (GDP). The current GDP has contributed to $6.2 \%$ in the first quarter of 2014. For five consecutive quarters, the construction sector continued to register impressive growth with

\footnotetext{
A.A. Zaini $(\bowtie)$

Department of Quantity Surveying, Faculty of Architecture Planning and Surveying, Universiti Teknologi MARA, Shah Alam, Sarawak, Malaysia

e-mail: afzanahmadzaini@gmail.com

I.R. Endut

Faculty of Civil Engineering, Universiti Teknologi MARA, Shah Alam, Sarawak, Malaysia e-mail: z_intan@yahoo.com

R. Hassan et al. (eds.), InCIEC 2014, DOI 10.1007/978-981-287-290-6_21
} 